\title{
Ways on Developing the Ability of Listening, Speaking, Reading and Writing
}

\author{
Zhiyong Sun \\ Chifeng University 024000
}

\begin{abstract}
The paper aims at how to develop secondary school students' abilities of Listening, Speaking, Reading and writing. listening, speaking, reading and writing are basic abilities in learning English. Through investigations, the writer finds that there are some obstacles to hinder students from improving their abilities in Listening, Speaking, Reading and writing, and then impede the progress of English achievement.The paper analyses the ways on how to developing the four abilities separately, and show some examples.
\end{abstract}

\section{Key Words- ability, learning, english, way}

\section{Introduction}

The purpose of middle school English teaching is to improve the students' four skills of listening, speaking, reading and writing, with the base of necessary phonetics, large vocabulary and good grammar, But this is not the final purpose. The final purpose is to let students be able to use the language.

Why do we study English? If a man is only good at listening and speaking, can we say that he is good at English? No, If a man is only good at reading and writing, can we say that he is good at the language? No, If a student is good at English, he should be able to use the language, both in speaking and writing.

Now most of the students do better in reading and writing English than in listening and speaking. They can read and write, but they can hardly communicate. They can hardly express themselves with their own words. This is partly because of our examination system, and partly because of the teaching methods. We are not able to change the examination system, but we can improve our teaching methods.

Most of all the teachers like to teach their students a lot of knowledge-words, phrases, grammar, usages and so on, They are focusing these thing, especially on the grammar. Yes, the students do need these, but many teachers forget to teach them how to study English, and how to use it. So when you are giving the knowledge to the students, don't forget to teach them all the abilities of the four skills.

\section{Ways on developing the four abilities 1. Listening}

The teachers often speak of the four skillslistening, speaking, reading and writing. That means each of them is important. You can't say that you have mastered the language without any one of them, Listening, one of the means of language communication, is used most widely in people's daily lives. About $45 \%$ of an adult's time concerns listening to other people, listening to the radio, listening to the music. In linguistics , giving the students a lot of listening activities is a good way of enlarging their vocabulary. On the other hand, it also helps the students improve their listening comprehension.

Someone has done an investigation. About $43.2 \%$ of the students think that the most bothering and most difficult is listening comprehension, and even some of them have difficulty in understanding their teacher who gives lessons in English.

Without question, it is difficult of a middle school student to understand the listening material, if he hasn't enough vocabulary and the ability of telling the grammar construction. In the investigation, about $35 \%$ of the students with low 
listening comprehension thing this is because they don't understand or know the knowledge about linguistic, they are not able to tell the means of a what they have heard. In another investigation, students were asked to listen to a dialogue of 244 words, in which the words and grammar have already been learned. But $80 \%$ of them thought it was too difficult. Then, using the same dialogue as a reading comprehension material, I found only $5 \%$ of them thought it was a little difficult, on the other hand the response ability is also another reason.

It is clear that the reading speed of a material also affects. About $43 \%$ of the students thought that the material was read too fast and they couldn't follow.

A lot of students have their own listening habits. Some students often try to understand each word or each sentence. They will think hard when they meet some difficult words or sentences, and a great many students could understand the material directly, They often translate the English into Chinese in their heart, thinking that only in this way can the sentence be understood. This is also a reason, trying to understand each word is difficult, and it is not necessary at all. You should catch the most important points.

Then how to improve the students' listening skill?

We know the largest difference between mother language learning and foreign language learning is the environment. A child can soon learn his mother language well. He has heard a lot before he can say something and walk. Then after he is able to walk and say, he has a chance of listening to more. Before he goes to school, he has already been a good listener and speaker.

But for a foreign language, you can meet it only in formal places, classes, for example, otherwise, you can hardly have a chance to meet it. So I think you should try to let the students be in a language environment.

Let the students grasp the phonetic symbol. I think the phonetic symbol is the base. A good intonation and phonetic depends on the base. Oral reading after a radio or a teacher is a good way at the beginning, Students should do much about it.

Pay attention to the oral reading skill, It includes stress, strong form, weak form, intonation incomplete plosive consonant, affricate consonant, syllable and so on. Training and practicing the oral reading is not a day's word. The teacher must give correct information about it . There is no easy way.

Enlarge the students' knowledge about English. Encourage the students to read something in their spare time about geography, history, culture, stories and so on. For example, there are two materials of the same difficulty. One explains something about China's Spring Festival, the other is about Thanks giving Day of the western countries. The former is easy to understand but the latter is more difficult. Why? It is clearly because the students know little about the latter.

Both listening test and listening practice are necessary, but practice is more important. You can understand your students through listening tests. Only through the practice can the students improve their listening comprehension.

\section{Speaking}

Speaking can't be taught separately. It is often connected with listening. So we often speak of listening and speaking. The traditional way of listening and speaking is aural-oral method. Now, the new method of two-way communication is very popular.

As you know that any teaching method has its psychological base. The aural-oral method began in the 1940's. It is based on behaviourism. One of its psychological theory is that learning a language is forming a set of new language habit.

This is its usual process: StimulusResponse-Reinforcement.

The aural-oral method is fit for the teaching of beginning stage. It focuses on the practice of oral English drills. But too many drills are being practiced without any context or given conditions. So what is learned is isolated clauses. And it has few communicative functions .

The two-way communication makes up for 
the defect in communicative ability in the traditional teaching. Two-way means the relationship of the communication between the teacher and the students. This relationship is connected with the communicative activities between two people. This method is different from the traditional aural-oral method. But it also bases on the process of S-R-R. So we call it a mew type of aural-oral method has some peculiarities. It can create a fresh environment for speaking English. It needs some necessary explanations of Grammar, including some sentence structures. Hints are the major way of practice. Teachers can control the practice wholly or partly.

The practice can also be controled by students freely. The internal force of study is not due to the interests in phonetic structure, but the content of the material. To make the correct response, the students are asked to pay more attention.

\section{Reading}

Reading is an important way of gaining information in foreign language learning, It is a basic skill for a foreign language learner. There is a lot of reading exercises in an examination today. But all these readings must be done in limited time. So students are asked to read them correctly and with a certain speed. To do this, you should change your bad reading habit and raise your reading efficiency. New words prevent you from reading fast. One way to overcome this problem is to guess. There are many ways to guess the meaning of a new word. First you should find some hints. Context, some phrases, such as "means", "refer to", "in other words", "That is to sag"; are all the hints.

Model 1.

A middle-aged professor said that his wife was too extravant, because no matter how much he give her for the household expenses, she always ran short. In this sentence, the meaning of the word "extravagant" can be easily guessed.

Model 2.

Prometheus stayed chaied to the lock for many years, Then at last the mighty.

Hercules came forth and broke the bonds -but that is another of the wonderful stories of the Greeks. In This pargraph, the words "stayed chained" is the hint, So you can guess what "bonds" means. Model 3.

The tiny droplets that form on dust particles very small pieces of dust, to produce a cloud are far apart from each other. In this sentence, the words after the dash shows the meaning of the word "partides". Besides the ways mentioned above, you can guess according to the wordformation, for example Child-childless, MarxMarxism, Large-enlarge, tell-foretell, Australian satellite $\rightarrow$ Aussate, State run $\rightarrow$ state-run.

Sometimes you can't guess what the word means. If the word doesn't affect your reading, let it be. For example, A German told me that all over China they use Gourmet powder in their food. It will give you higher blood pressure. You may know that gourmet it a kind of thing that can be eat. But it doesn't matter whether you know what it is. Another problem that affect your reading speed is you reading habit and you reading skill. Some one reads word by word. Some one reads with his finger pointing to the words or with his head shaking. Those are all bad habits. You should read phrase by phrase. Don't blink your eyes so often and don't shake you head. Just move your eyeball. That's enough. If you want to get more word information, there must be a proper distance between your eyes and the reading material.

I think browsing is an important step while you are doing you reading comprehension. Some students begin to read at once when he get a reading material, even without knowing, its title. But after reading for many times, he won't understand what the article says.

In an examination, you want to grain the information which the questions ask, you can't read the material in a usual way, you can't read the whole material word by word. You have to omit some sentence, sometimes even a whole paragraph, which have nothing to do with the questions. I think you might read the given 
questions fast as well, then the material. There is an advantage to do this. When you read the material with the questions, you can save your time.

\section{Models:}

A. Festival Atmosphere.

At midnight on New Year's Eve, people in Rome, Italy, throw out all the things they no longer want. The streets are filled with old chairs, beds, clothes and dishes. In Madrid, Spain, the new Year comes in more quietly. People come to the main souare. Each holds a bag of grapes. As the clock strikes twelve, the people eat the grapes----one for each stroke. In Tokyo, capital of Japan, people eat noodles in New Year's Eve. This food is said to bring long life. Early the next morning, some Japanese families climb Mount Fuji, There they watch the first sunrise of the new Year.

1. This story is about New Year's Eve in
A. Europe
B. Europe and Latin Aucerica.
C. Four capital cities.
D. Three countries.

2. The writer thinks New Year's Eve in Rome is
A. interesting
B. dull
C. noisy
D. happy

3. The number of grapes that must be take. From each bag is
A. one
B. twelve
C. thirteen
D. fourteen

4. People in both Spain and Japan spend the New Year's Eve
A. throwing things away
B. eating a special food
C. climbing a mountain
D. watching the first sunrise
5. People climb Mount Fuji on the New Year's morning to
A. look for happiness

B. meet their friends

C. enjoy the beauty of nature

D. do something strange

6. People who hope to gain long life from their New Year's food are the
A. Japanese
B. Spanish
C. Italians
D. both A and B

Look through the questions first. No. $1,3,4,6$ are the questions which are about the content of the article. This information is connected with the names, numbers or activities in the article, question No. 2 and No. 5 are comprehensive ones.

Then browse the article. From the questions and the title you may know that the article is about the festival custom of different countries. The article includes three paragraphs. Each talks of a different place ___ Rome, Madrid and Tokyo.

So when you have the first glance over the article, you've got the key to question No.1. After your glance, these things have been put into your brain: Rome-throw out-are filled with-

Madrid-quietly-main square-grapes-one for each stroke

Tokyo-noodles-bring long life-climb Mount

Fuji-first sunrise

Now, you may have some idea of the out line of the article, Then you may read the whole material

\section{Writing}

Writing is one way of providing variety in classroom procedures. It provides a student with physical evidence of his achievements and becomes a course whereby he can measure his improvement. It helps to consolidate the students' grasp of vocabulary and structure, and complements the other language skills. Sentence is the base of an article. So we should begin our writing with sentences. First, students should be asked to express with sentences-sentences making, then to write short articles.

\section{1). Translation. Translate Chinese into English.}

First, they should learn the five basic sentence drills. Then choose some typical 
sentences in the text as models, do sentence making after these models.

2). Sentence pattern exchanging. By rewriting the sentences, practise expressing the same meaning with different patterns.

3). Text shortening and rewriting. It helps to understand the text, and helps to write compositions. It can foster students' ability to summarize and to use the language freely.

\section{Conclusion}

While you are training these four skills, you'd better make full use of your teaching instrument use varieties of ways to stimulate the students' interests. Generally speaking these four skills can't be separated. People often say "First listening and speaking, then reading and writing". That's right. But I think this way of saying is fit for the beginning stage. For a senior middle school student, reading and writing is more important.

Before you are going to have a new lesson, do reading and writing first. Ask students to read the text in advance, and do some exercises connected with the text. Listening and speaking are the major ways while teaching the new lesson. Be sure to let the lesson go on in a foreign language situation. You can ask the students questions about the text, do some discussion, check the students' homework. This helps students raise their ability of listening and speaking. It also helps to understand or comprehend the text and the sentences.

\section{Reference}

[1] Hanzhong $\mathrm{Fu}<<$ Bidirectional English $>>$, Beijing tricyclic Press .2008.11.

[2] Liuxi Zhou $<<$ Encyclopedia of Chinese high school English education >>. Northeastern University Press .2002.9.

[3] Tingxiang $\mathrm{Li}<<$ Teaching English $>>$. Higher Education Press .2006.3.

[4] Huang Yuefa 《 English Teaching Methodology》2007.5. 